Variasi Kemasan Terhadap Tingkat Kesukaan dan Pengambilan Keputusan - Erijanto, dkk Jurnal Pangan dan Agroindustri Vol.6 No.1: 91-96, Januari 2018

\title{
VARIASI KEMASAN TERHADAP TINGKAT KESUKAAN DAN PENGAMBILAN KEPUTUSAN KONSUMEN PADA PEMBELIAN MAKANAN TRADISIONAL: KAJIAN PUSTAKA
}

\section{Packaging Variety towards Favorite Levels and Consumers' Decision Making on Purchasing Traditional Foods: Literature Review}

\author{
Adhelia Christina Erijanto*, Kiki Fibrianto \\ Jurusan Teknologi Hasil Pertanian, FTP Universitas Brawijaya Malang \\ Jl. Veteran, Malang 65145 \\ *Penulis Korespondensi: adhel.christina@gmail.com
}

\begin{abstract}
ABSTRAK
Kemasan memiliki peran yang sangat penting, tidak hanya dalam melindungi produk agar tidak rusak dan menjaga kualitas produk, namun juga berfungsi dalam proses pengenalan produk, persepsi konsumen mengenai produk, kesadaran konsumen terhadap eksistensi produk hingga bersedia untuk membeli bahkan menjadi pelanggan suatu produk, dan merupakan jati diri suatu produk. Kemasan pangan terdiri dari dua kategori yaitu kemasan tradisional seperti daun tanaman dan kemasan modern yang meliputi plastik dan kertas. Atribut kemasan yang berperan dalam mempengaruhi pengambilan keputusan pembelian konsumen adalah bahan, bentuk, warna, dan ukuran kemasan.

Kata kunci: Hedonik, Jajanan Tradisional, Pengambilan Keputusan, Sensori.

ABSTRACT

Packaging has a very important role, not only to protect products and keep the good quality but also in the process of product recognition, consumer awareness of products, consumer awareness of the products existence so that they willing to purchase more products, on the top of that they become a loyal costumer of a brand, even more packaging has become an identity of a brand or product. Food packaging consists of two categories: traditional packaging such as plant leaves and modern packaging such as plastics and papers. The packaging attributes that involved in the consumers' decision making of purchasing a product are materials, shapes, colors, and packaging sizes.
\end{abstract}

Keywords: Decision Making; Hedonics; Sensory; Traditional Snack.

\section{PENDAHULUAN}

\section{Makanan Tradisional}

Makanan tradisional adalah makanan yang diturunkan dan telah membudaya di masyarakat Indonesia, pekat dengan tradisi setempat (Winarno, 1993), dan menimbulkan pengalaman ingatan tertentu dengan nilai gizi yang cukup menjangkau (Europen Communities, 2007). Makanan tradisional juga dapat didefinisikan sebagai makanan umum yang sudah ada dan biasa dikonsumsi sejak beberapa turunan, terdapat beberapa hidangan yang sesuai 
dengan selera manusia, tidak bertentangan dengan keyakinan agama masyarakat daerah tersebut, dan diracik dari bahan-bahan makanan dan rempah-rempah yang ada di lokal (Sastroamidjojo, S, 1995). Menurut Guerrero (dalam Verbeke, 2011) makanan tradisional adalah makanan yang dikonsumsi secara berkala pada suatu perayaan atau musim tertentu yang dilakukan turun temurun dari satu generasi ke generasi lainnya, dibuat dengan cara spesifik dengan proses yang sederhana, dibedakan dan dikenal berdasarkan sifat sensorik serta dikaitkan dengan budaya pada suatu daerah.

Menurut Sosrodiningrat (dalam Marwanti, 2000) ciri-ciri makanan tradisional adalah sebagai berikut:

- Resep makanan didapatkan turun temurun dari generasi terdahulu

- Penggunaan alat tradisional tertentu di dalam pembuatan masakan yang akan dibuat (misalnya masakan harus dibuat menggunakan kompor batu bata)

- Cara pembuatan masakan adalah pengolahan yang harus dilakukan untuk mendapatkan rasa maupun rupa yang khas dari suatu masakan.

\section{Kemasan Makanan}

Menurut Kotler dan Amstrong (2012), proses pengemasan meliputi kegiatan mendesain dan memproduksi, sedangkan fungsi utama kemasan adalah untuk melindungi suatu produk agar kualitasnya tetap terjaga hingga ke tangan konsumen. Tujuan dan fungsi kemasan dalam pembuatan produk menurut Titik Kotler dan Amstrong (2008) antara lain:

a. Memperindah produk dengan kemasan sesuai kategori produk

b. Memberikan keamanan produk agar tidak rusak saat dipajang di toko

c. Memberikan kemanan produk pada saat pendistribusian produk

d. Memberikan informasi pada konsumen tentang produk itu sendiri dalam bentuk pelabelan.

Kotler dan Keller (2012) menyatakan bahwa kemasan yang baik dapat membangun ekuitas merek dan mendorong penjualan. Beberapa faktor yang memiliki kontribusi penggunaan kemasan sebagai alat pemasaran antara lain:

a. Swalayan. Kemasan yang efektif melaksanakan tugas dalam penjualan antara lain: menarik perhatian, menggambarkan fitur produk, menciptakan keyakinan konsumen, dan membuat kesan menyenangkan

b. Kekayaan konsumen. Peningkatan kekayaan konsumen membuat mereka bersedia membayar lebih besar untuk kenyamanan, penampilan, keandalan, dan gengsi untuk kemasan yang lebih baik

c. Perusahaan dan citra merek. Kemasan mempunyai peran terhadap pengakuan segera atas perusahaan atau merek

d. Peluang inovasi. Kemasan yang inovatif dapat membawa manfaat besar bagi konsumen dan laba bagi produsen.

Dari beberapa data di atas dapat diambil kesimpulan bahwa kemasan memiliki peran yang sangat penting. Tidak hanya dalam melindungi produk agar tidak rusak dan menjaga kualitas produk, namun juga berfungsi dalam proses pengenalan produk, persepsi konsumen mengenai produk, kesadaran konsumen terhadap eksistensi produk hingga bersedia untuk membeli bahkan menjadi pelanggan suatu produk, dan merupakan jati diri suatu produk. Disamping itu, kemasan juga berfungsi dalam memberikan informasi mengenai produk tersebut meliputi komposisi yang digunakan hingga bahan-bahan yang dapat menimbulkan alergi atau penyakit tertentu, sehingga konsumen dapat mengambil keputusan dengan lebih hati-hati.

Adanya kemasan tradisional tidak lepas dari keberagaman budaya yang dimiliki oleh Indonesia, salah satunya terletak dalam keanekaragaman makanan tradisional. Keterkaitan 
yang ada di dalamnya antara lain dalam proses produksi atau pengolahan dan proses pembuatan kemasan. Kemasan tradisional yang digunakan dalam suatu produk pada umumnya tidak lepas dari budaya dan adat istiadat yang tumbuh pada suatu daerah tertentu. Bahan kemasan alami atau tradisional ditinjau dari keberadaannya, jumlahnya yang masih banyak di lingkungan, dan tidak menyebabkan dampak yang negatif apabila digunakan bersama dengan makanan bahkan bahan kemasan alami dapat terurai oleh bakteri secara alamiah (Noviadji, 2014).

Kemasan tradisional yang masih banyak digunakan di Indonesia antara lain kayu, bambu, dan daun maupun kulit tanaman. Penggunaan daun sebagai bahan pengemas didasarkan pada alasan harga yang sangat terjangkau, mudah didapat, ketersediaan di alam yang masih melimpah, dan praktis digunakan, namun kemasan dari daun kurang representatif, sehingga saat digunakan harus dengan hati-hati (Noviadji, 2014).

\section{Persepsi Konsumen}

Pengertian persepsi menurut Kotler (2000) adalah proses yang digunakan oleh individu untuk memilih, mengorganisasi, dan menginterpretasi masukan informasi guna menciptakan gambaran yang memiliki arti. Persepsi tidak hanya tergantung pada rangsangan dalam bentuk fisik, tetapi juga tergantung pada rangsangan yang ada disekitarnya dan kondisi yang ada pada seseorang, dimana hal tersebut menyebabkan persepsi lebih penting dibandingkan realitas dalam pemasaran. Hal tersebut yang pada akhirnya dapat mempengaruhi pengambilan keputusan seseorang saat dihadapkan pada pilihan atau objek yang sama.

\section{Uji Afektif (Affective Test)}

Pada prinsipnya uji organoleptik dibagi menjadi 3 yaitu uji pembeda (discriminative test), uji deskripsi (descriptive test) dan uji afektif (affective test).Uji pembedaan digunakan untuk memeriksa apakah ada perbedaan diantara contoh-contoh yang disajikan. Uji deskripsi digunakan untuk menentukan sifat dan intensitas perbedaan tersebut. Kedua kelompok uji di atas membutuhkan panelis yang terlatih atau berpengalaman. Sedangkan uji afektif didasarkan pada pengukuran kesukaan (atau penerimaan) atau pengukuran tingkat kesukaan relatif. Pengujian Afektif yang menguji kesukaan dan/atau penerimaan terhadap suatu produk dan membutuhkan jumlah panelis tidak dilatih yang banyak yang sering dianggap untuk mewakili kelompok konsumen tertentu (Stone dan Joel, 2004).

Uji afektif meliputi digunakan untuk mengukur sikap subjektif konsumen terhadap produk berdasarkan sifat-sifat organoleptik. Hasil yang diperoleh antara lain penerimaan (diterima atau ditolak), kesukaan (tingkat suka/tidak suka), pilihan (pilih satu dari yang lain) terhadap produk. Metode ini terdiri atas uji perbandingan pasangan (paired comparation), uji hedonik, dan uji ranking (Stone dan Joel, 2004).

Prosedur uji perbandingan pasangan adalah dua contoh yang diberi kode disajikan bersamaan dengan cara penyajian yang sama, misalnya dalam bentuk ukuran, suhu dan wadah. Panelis diminta memilih mana yang disukai. Untuk mendapatkan hasil yang baik, jumlah panelis disarankan lebih dari 50 orang (Susiwi, 2009).

Uji hedonik merupakan pengujian yang paling banyak digunakan untuk mengukur tingkat kesukaan terhadap produksi. Tingkat kesukaan ini disebut skala hedonik, misalnya sangat suka, suka, agak suka, agak tidak suka, tidak suka, sangat tidak suka dan lain-lain. Skala hedonik dapat direntangkan atau diciutkan menurut rentangan skala yang dikehendaki. Dalam analisis datanya, skala hedonik ditransformasikan ke dalam skala angka dengan angka semakin naik menurut tingkat kesukaan (dapat 5, 7 atau 9 tingkat kesukaan), dimana data yang sudah didapatkan akan dilanjutkan dengan analisa statistik(Susiwi, 2009). 
Prinsip uji hedonik adalah panelis diminta tanggapan pribadimengenai kesukaan atau ketidaksukaan terhadap komoditi yang dinilai. Dalam bidang pangan analisa hedonikdigunakan dalam hal pemasaran, yaitu untuk memperoleh pendapat konsumen terhadap produk baru, hal ini diperlukan untuk mengetahui perlu tidaknya perbaikan lebih lanjut terhadap suatu produk baru sebelum dipasarkan. Selain itu uji ini digunakan untuk mengetahui produk yang paling disukai oleh konsumen (Susiwi, 2009).

Dalam uji rangking diuji 3 atau lebih contoh dan panelis diminta untuk mengurutkan secara menurun atau naik menurut tingkat kesukaan (memberi peringkat). Panelis dapat diminta untuk meranking kesukaan secara keseluruhan atau terhadap atribut tertentu seperti warna atau flavor. Contoh sampel diberi kode dan disajikan secara seragam, dan disajikan bersamaan. Panelis diminta menyusun peringkat atau ranking berdasarkan tingkat kesukaan (Susiwi, 2009).

\section{Analythical Hierarchy Procces (Ahp)}

Analytical Hierarchy Process (AHP) adalah salah satu metode khusus dari Multi Criteria Decision Making (MCDM) yang diperkenalkan oleh Thomas Lorie Saaty pada tahun 1970. AHP banyak digunakan untuk memecahkan masalah pada suatu situasi yang kompleks. Yang dimaksud dengan masalah yang kompleks adalah kriteria dari suatu masalah yang banyak (multikriteria), struktur masalah yang belum jelas, ketidakpastiaan pendapat dari pengambil keputusan, pengambil keputusan lebih dari satu orang, serta tidak akuratnya data yang tersedia (Darmanto, 2014).

\section{Uji Friedman}

Uji Friedman merupakan metode nonparametrik yang digunakan untuk rancangan acak kelompok lengkap. Uji Friedman memiliki tujuan untuk melihat ada atau tidaknya perbedaan pengaruh antar perlakuan. Apabila perlakuan-perlakuan yang diberikan memiliki pengaruh yang berbeda, respon dari subjek yang diberi perlakuan akan memiliki median yang sama dengan respon dari subjek yang diberi perlakuan lainnya, setelah pengaruh pengelompokkan peubah dihilangkan (Departemen Statistik FMIPA IPB, 2010).

\section{Pengambilan Keputusan}

Dalam Kamus Besar IImu Pengetahuan pengambilan keputusan (Decision Making) didefinisikan sebagai pemilihian keputusan atau kebijakan yang didasarkan atas kriteria tertentu. Proses ini meliputi dua alternatif atau lebih karena seandainya hanya terdapat satu alternatif tidak akanada satu keputusan yang akan diambil (Dagum, 2006).Pengambilan keputusan merupakan salah satu bentuk perbuatan berpikir dan hasil dari suatu perbuatan itu disebut keputusan. Pengambilan keputusan dalam Psikologi Kognitif difokuskan kepada bagaimana seseorang mengambil keputusan, dalam kajiannya berbeda dengan pemecahan masalah yang mana ditandai dengan situasi dimana sebuah tujuan ditetapkan dengan jelas dan dimana pencapaian sebuah sasarandiuraikan menjadi sub tujuan, yang pada saarnya membantu menjelaskan tindakan yang harus dan kapan diambil (Desminta, 2008). Pengambilan keputusan merupakan suatu pendekatan yang sistematis terhadap hakikat alternatif yang dihadapi dan mengambil tindakan yang menurut perhitungan merupakan tindakan yang tepat, pembuatan keputusan terjadi di dalam situasi-situasi yang meminta seseorang harus membuat prediksi ke depan, memilih salah satu diantara dua pilihan atau lebih, membuat estimasi (perkiraan) mengenai frekuensi perkiraan yang akan terjadi (Suharman, 2005). 
Variasi Kemasan Terhadap Tingkat Kesukaan dan Pengambilan Keputusan - Erijanto, dkk Jurnal Pangan dan Agroindustri Vol.6 No.1: 91-96, Januari 2018

Menurut Schiffman (2008), proses pengambilan keputusan dapat dilihatdalam tiga tahap yang berbeda, namun satu dengan yang lainnya memiliki keterkaitan. Tahap-tahap tersebut antara lain adalah :

1. Tahap masukan

Tahap masukan mempengaruhi pengenalan konsumen terhadap kebutuhan atasproduk dan terdiri dari dua sumber informasi utama yaitu usaha pemasaranperusahaan (produk, harga, promosi, distribusi) dan pengaruh sosiologiseksternal atas konsumen (keluarga, teman-teman, tetangga dan sebagainya)

2. Tahap proses

Tahap proseslebih fokus pada cara konsumen mengambil keputusan. Prosespengambilan keputusan konsumen meliputi lima tahap yaitu: adanya masalah, pencarian alternatif, pemecahan, evaluasi alternatif pembeli, penggunaan pasca pembeli, dan evaluasi tentang alternatif yangakan dipilih.

3. Tahap output

Model pengambilan keputusan konsumen menyangkut dua kegiatan pascapembelian yang berhubungan erat dengan perilaku kosumen dan penilaianpasca membeli.

Aspek pengambilan keputusan (decision making) menurut Lucas dan Britt (Dalam Prabastiningrum, 2011) yang dilakukan oleh individu (decision maker) biasanya didasarkan atas:

a. Perhatian (Attention), sejauh mana produk mampu menjadi pusat perhatian konsumen atau tidak

b. Ketertarikan (Interrest), yaitu sejauh mana calon konsumen menjadi tertarik pada produk yang ditawarkan pemasar

c. Keinginan (Desire), yaitu sejauh mana penawaran yang diciptakan pemasar mampu memunculkan rasa keinginan atau kebutuhan konsumen untuk membeli atau memiliki produk yang ditawarkan

d. Keyakinan (Conviction), yaitu sejauh mana individu yakin akan produk yang ditawarkan adalah bermutu dengan harga yang kompetitif

Keputusan (Action), yaitu sejauh mana individu melakukan pembelian terhadap produk yang ditawarkan atau melakukan penawaran terhadap produk yang

\section{DAFTAR PUSTAKA}

Dagum, M Save. 2006. Kamus Besar IImu Pengetahuan. Jakarta: Lembaga Pengkajian Kebudayaan Nusantara (LPKN).

Darmanto, Eko. Et al. 2014. Penerapan Metode AHP (Analityc Hierarchy Process) Untuk Menentukan Kualitas Gula Tumbu. Universitas Muara Kudus. Kudus

Departemen Statistik FMIPA, IPB. 2010. Analisis Dasar Kategorik (STK351). Institut Pertanian Bogor. Bogor

Desminta. 2008. Psikologi Perkembangan. Bandung: Remaja Rosdakarya.

European Commission, Directorate-General for Research. 2007. European Research on Traditional Foods. http://www.fp7.org.tr/tubitak_content_fle/268/dokumanlar/traditionalfoods.pdf. Tanggal akses: 01/03/2018.

Kotler dan Amstrong, Yudhi. 2008. Kualitas Produk, Merek dan Desain Pengaruhnya Terhadap Keputusan Pembelian Sepeda Motor Yamaha Mio. Jurnal EMBA. 1:3, 06

Kotler, Philiph dan Amstrong, Gary. 2006. Prinsip-prinsip Pemasaran, Erlangga, Jakarta.

Kotler, Philip. 2000. Manajemen Pemasaran, Edisi Milenium. Prehallindo. Jakarta

Marwanti. 2000. Pengetahuan Masakan Indonesia. Adicita Karya Nusa. Yogyakarta 
Noviadji, Rahmawan. B. 2014. Desain Kemasan Tradisional dalam Konteks Kekinian. Fakultas Seni IKADO. Surabaya

Prabastiningrum, Ferin. F. 2011. Hubungan Antara Persepsi Konsumen terhadap Produk dengan Keputusan Membeli Handphone Qwerty. Skripsi: Undip. Semarang

Sastroamidjojo, S. 1995. Makanan Tradisional, Status Gizi, dan Produktivitas Kerja. Prosiding Widyakarya Nasional Khasiat Makanan Tradisional. Kantor Menteri Negara Urusan Pangan, Jakarta

Schiffman dan Kanuk. 2008. Perilaku konsumen. Edisi 7. Indeks. Jakarta

Stone, Herbert dan Joel L Sidel. 2004. Sensory Evaluation Practices, Edisi Ketiga. Elsevier Academic Press. California, USA

Suharman. 2005. Psikologi Kognitif. Srikandi. Surabaya

Susiwi, S. 2009. Penilaian Organoleptik. Universitas Pendidikan Indonesia. Bandung

Verbeke, Wim. 2011. Consumers' Expectetion towards Traditional Foods. Department of Agricultural Economics, Ghent University. Belgium

Winarno, F.G., 1993. Pangan Gizi Teknologi dan Konsumen. Gramedia Pustaka Utama. Jakarta 